تحليل استراتزيك رويكرد يرداخت بابت خدمات اكوسيستم (PES)

بهنظور كاهش بهرهبردارى از مرتع

عليمحمد محمدى'، سيد عليرضا موسوى"'، سعيد سلطانى كويايى' و غلامحسين كيانى '

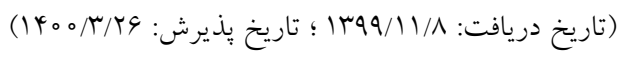

جكيده

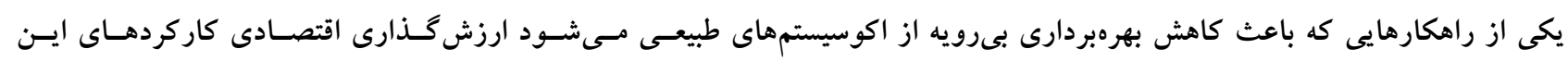

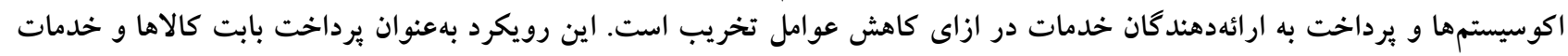

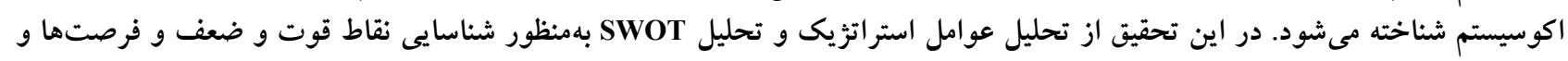

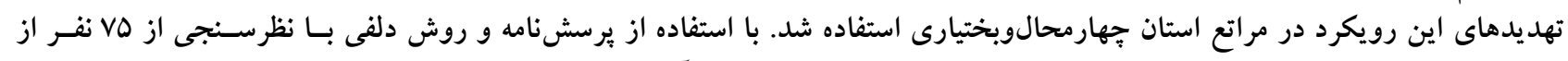

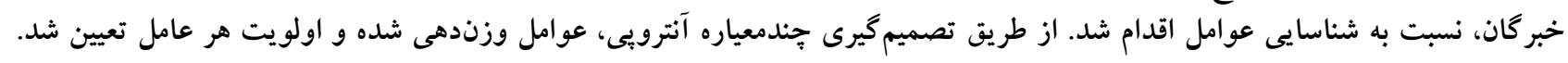

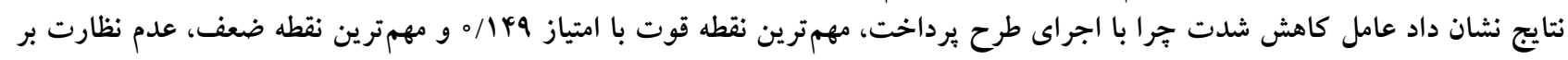

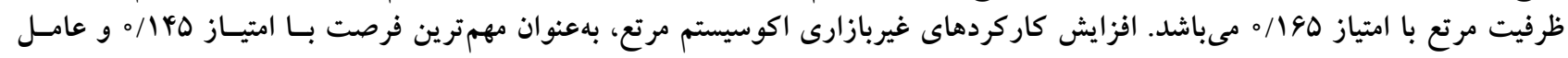

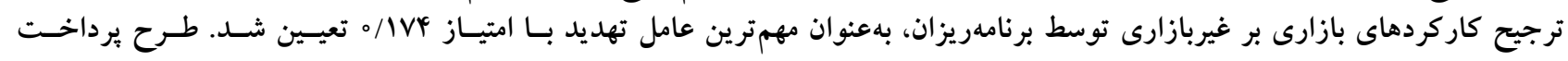

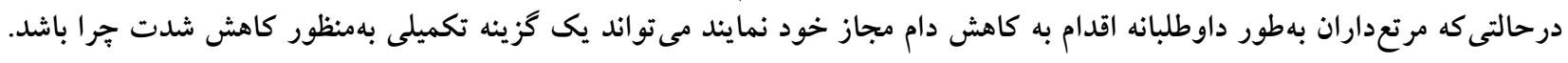

وازههاى كليدى: ارزش گذارى اقتصادى، تحليل عوامل استراتزيك، كاركردهاى بازارى، شدت جرا، مراتع جهارمحالوبختيارى

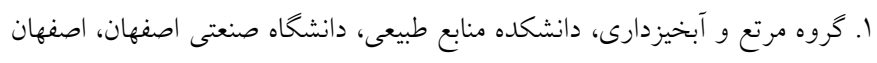

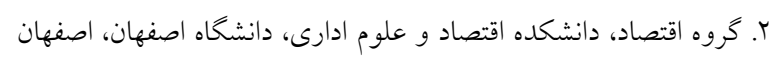

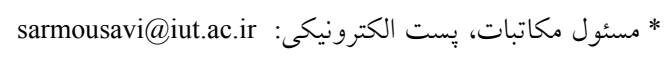


كالاهاى عمومى هستند و خــدمات محسيطزيستى آنهـا در بـازار

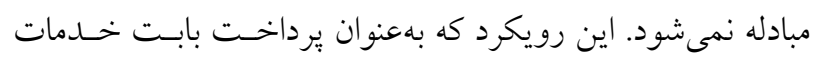
اكوسيسـتم (PES=Payment for Ecosystem Services) شـناخته

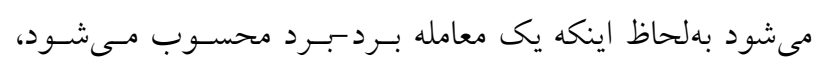

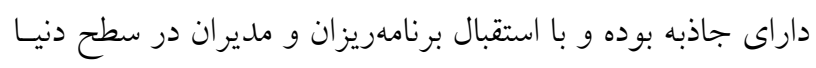

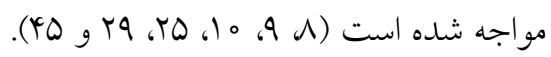

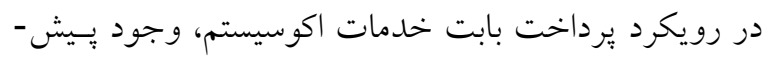

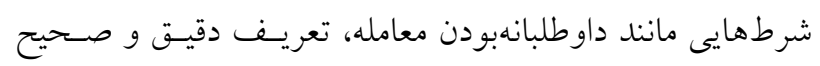

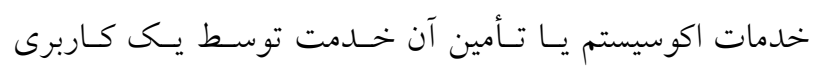

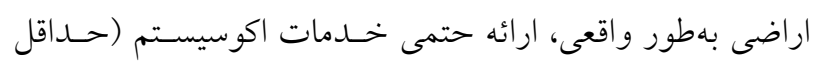

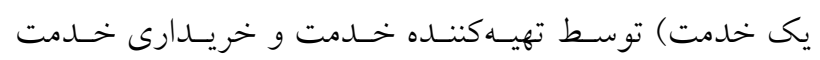

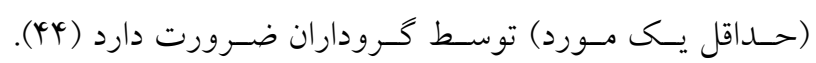

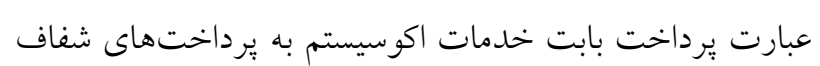

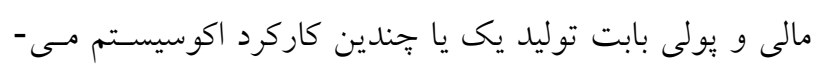

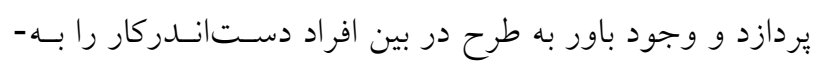

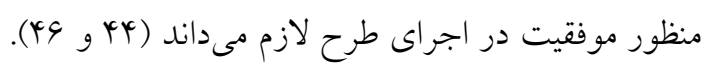

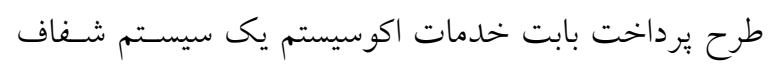

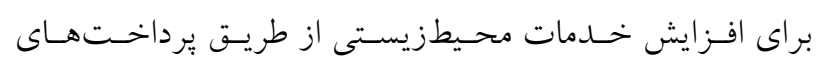

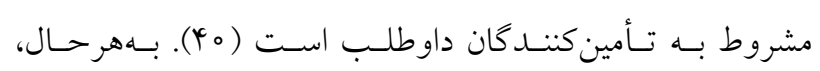

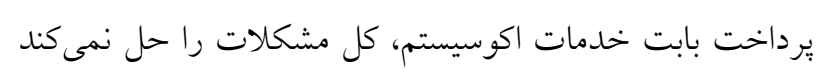

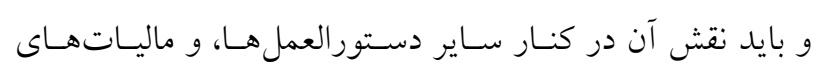

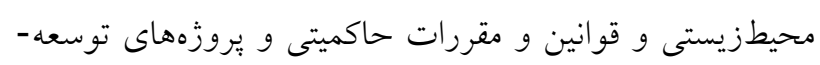

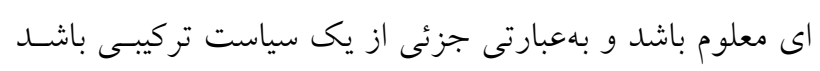

در مطالعه انجامشــه در مراتع خراسـان شـمالى، رويكــد يرداخت بابت خدمات اكوسيستم مرتع بهعنوان يكى از گزينهـ-

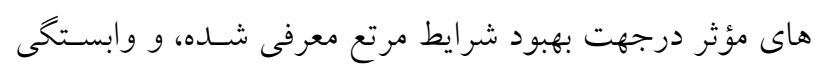

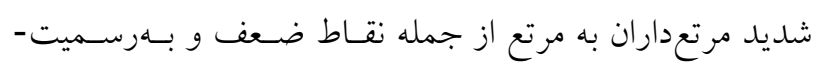

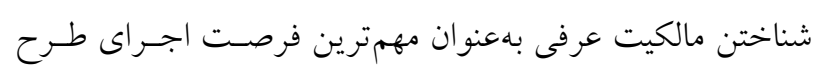

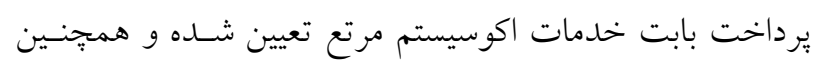

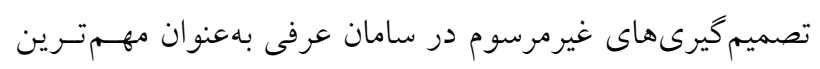

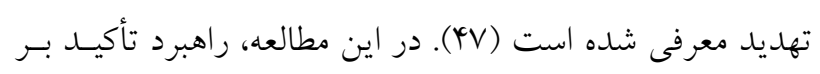

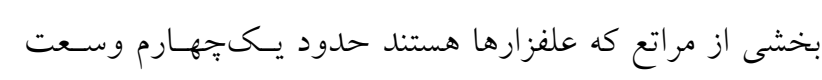

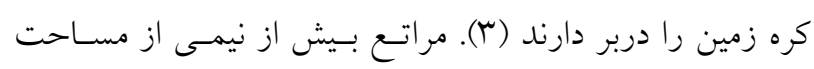

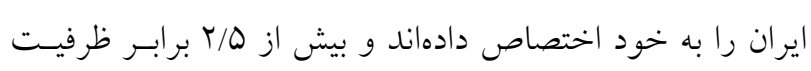

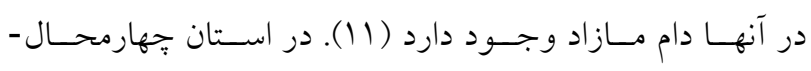

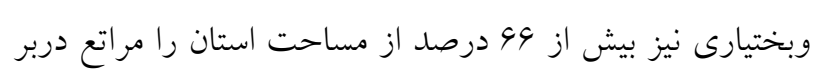

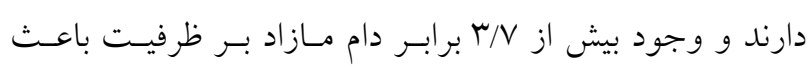
״ر اى مفرط در آنها شده است (اس). بنابر اين مراتع كه بيشترين

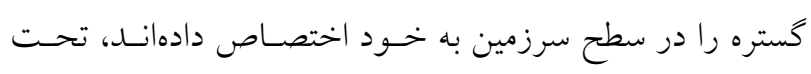

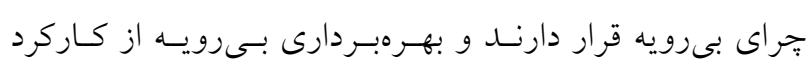

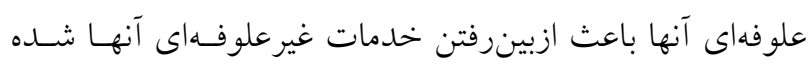
است. نوع بشر همواره براى بقاى خود نيازمنـــ كالاهــا و خــدمات

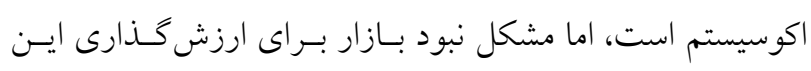

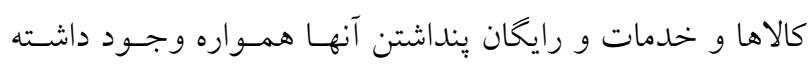

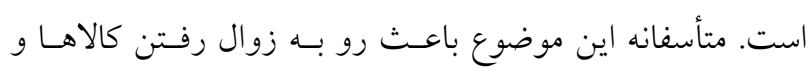

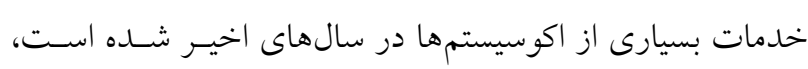

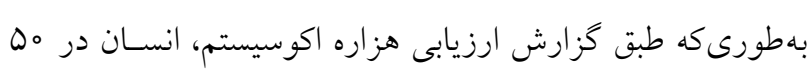

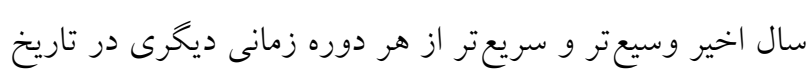

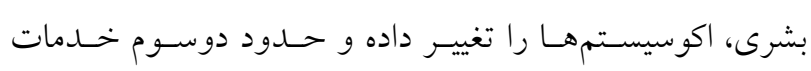

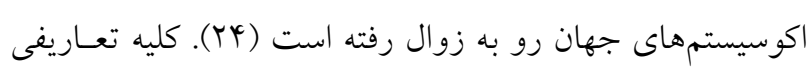

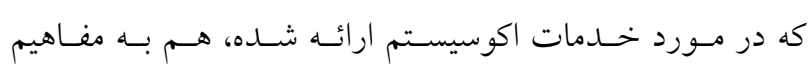

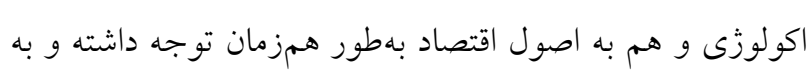

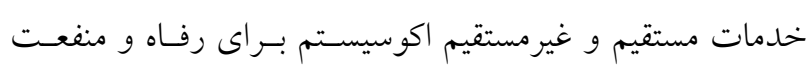
انسان تأكيد و اشاره دارند (†). اقتصاددانان محيطزيست معتقدند كه ارزش كذارى كاركردهـا،

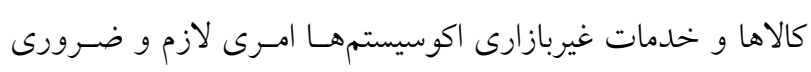

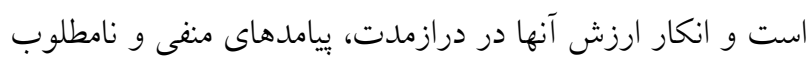

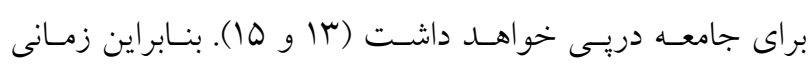

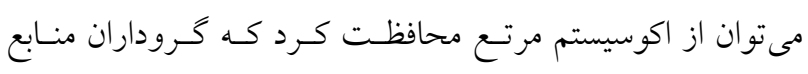
طبيعى (ذىنفعان) (Y (Y) بهاى كليه خدماتى كه اكوسيستمهـا ارائسه

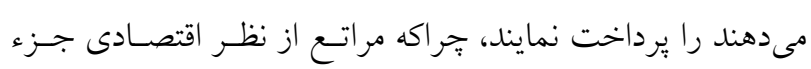


شده است (اسY). دامداران در فصل تابستان، دام خود را در ايسن مراتع تعليف مىنمايند و با شروع فصل سرد در اواسط ياييز بـهـ مراتع گرمسيرى جابجا مىشوند يا دامهايشـان را در اصـطبل در خانههاى روستايى نخهارى مى كنند ( أl). منطقه مـورد تحقيـق بهلحاظ ساختار اقتصادى اجتماعى - اكولوزيــى نماينـده سـطح وسيعى از مراتع كشـور و بخـش عمــدهاى از مراتـع خاورمياتـهـ

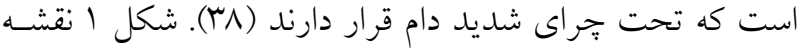
موقعيت منطقه مورد مطالعه را در كشور و استان نشان مىدهد.

\section{PES تعيين عوامل بيرونى و درونى اثر گذار بر اجراى طرح} يكى از ابزارى كه مى تواند ضمن ارائسه تحليـل مناسـب، امكـان

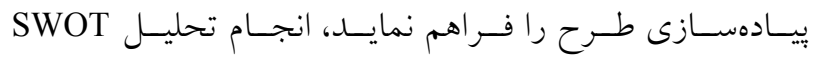
، (Strengths-Weaknesses-Opportunities-Threats) rY و YYY). اين ابزار، عوامل درونى سيستم شامل نقـاط قـوت و ضعف و عوامل بيرونى تأثير خذار شامل تهايدها و فرصتهـا را رانيا تحليل مى كند و با ارائسه، يـك مـاتريس، اسـتراتزى يـيش رو را

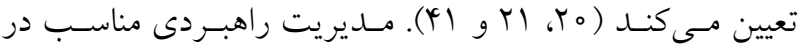
طرح PES منوط به شناسايى عو امل مختلف تأثير گذار درونسى و بيرونى اسـت. بــايسنـنظـور، نتـاط قـوت و ضـعف درونسى و تهاديدات و فرصتهاى بيرونى طـرح PES بـا تعيـين مـاتريس

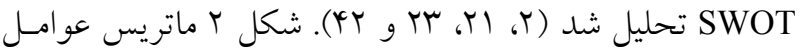
بيرونى و درونى مؤثر بر اجراى طرح برداخــت بابـت خــدمات اكوسيستم را ارائه مى دهد.

تعيين نمونه بر اساس آشنايى كارشناسان با طـرح برداخــت بابت خدمات اكوسيستم و تخصسص و تجربـه كـارى در زمينـه مرتع بود. ابتدا در جامعسهُ آمـارى، افـراد متخصسص و باتجربـهـ شناسايى شدند و بهصورت تصادفى نسبت به انجـام نظرسـنجى از مبارشناس اقدام شد. با توجه به ياسخهاى حاصل از نظرسنجى در مورد اجـرا يـا عدم اجراى طرح برداخت بابت خدمات اكوسيستم، نسـبت pو (n) محاسبه و با استفاده از رابطه ا، تعداد كل نمونه مورد نياز q جهـت تكميـل :برسشـنامههـاى مـورد نظـر تعيـين شـــ (V).

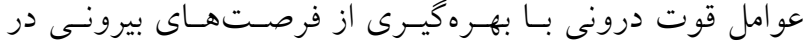
اجر اي طـرح يرداخــت بابـت خــدمات اكوسيسـتم مرتـع ارائسه.

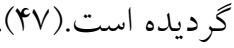
ييادهسازى طرح يرداخت به شناخت بيشزمينهها، قـوانين و

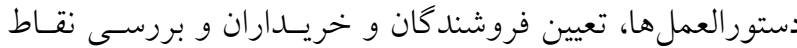
قوت و ضعف و تهديدات و فرصتهـا و مشـكاتل يـيشروى آن نياز دارد. هدف از اين تحقيق، تعيين عوامل درونى و بيرونى اثر كذار بر طرح يرداخـت بابـت خـــمات اكوسيسـتم مرتـع در راستاى كاهش فشار جرهراى دام و افـزايش تـوان توليـدى مراتـع

\section{مواد و روشا}

ايـن مطالعـه، تحليـل اجــراى طـرح برداخــت بابـت خـــمات اكوسيستم در مراتع نيمهخشى استان جهارمحالوبختيارى و به طـور خـاص در ^ سـامان عرفى منطقـه بـارده و كرسـنك در شهرستان بن را شامل مىشود. تعيسين نقـاط قـوت و ضـعف و تهايدات و فرصـتهـا و مشـكالات يسيش روى اجـراى طـرح يرداخت بابـت خـدمات اكوسيسـتم از محورهـاى اصـلى ايسن تحقيق است. فرم رويشى جوامع گياهى مرتعى بهصورت بوتسه -

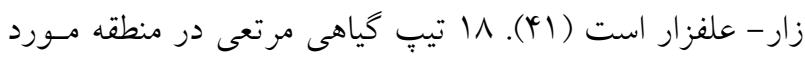
مطالعه تفكيك شد كه در V تيّ، جنس كون بهعنوان كونههـاى غالـب اول (Astragalus susianus \& Astragalus verus) و در

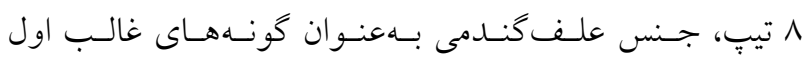
شناسـايى (Agropyron repens \& Agropyron intermedium) شد. در ץ تيٍّ نيز جنس بروموس و كنگر و گـراسهـاى يـك-

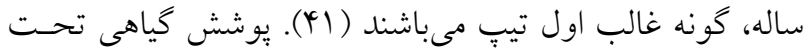
تأثير عوامل طبيعى مانند شيب، جهت، ارتفـاع، خـاك و زمسين شناسى و عوامل انسانى مانند شدت و مدت جرا تغيير مى كند و در نتيجه تأثير اين عوامل، مراتعى بـا طبقـه وضسعيت عـالى تـا خيلىفقير با گرايش متفاوت از منفى تا مثبـت بـا توليــ علوفـه.

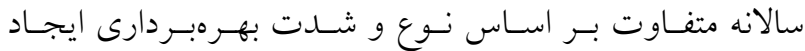
مىشود. تعداد بوأ دامدار مجاز در منطقه مورد مطالعه شناسايى 

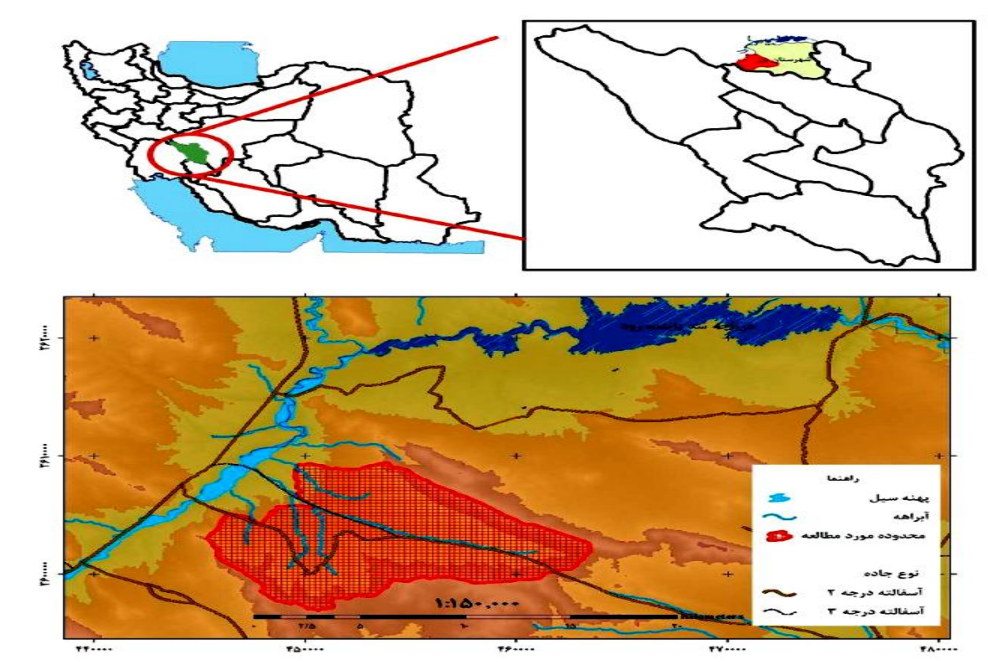

شكل 1. نقشه موقعيت منطقه مورد مطالعه در استان و كثور (رنكى در نسخه الكترونيكى)

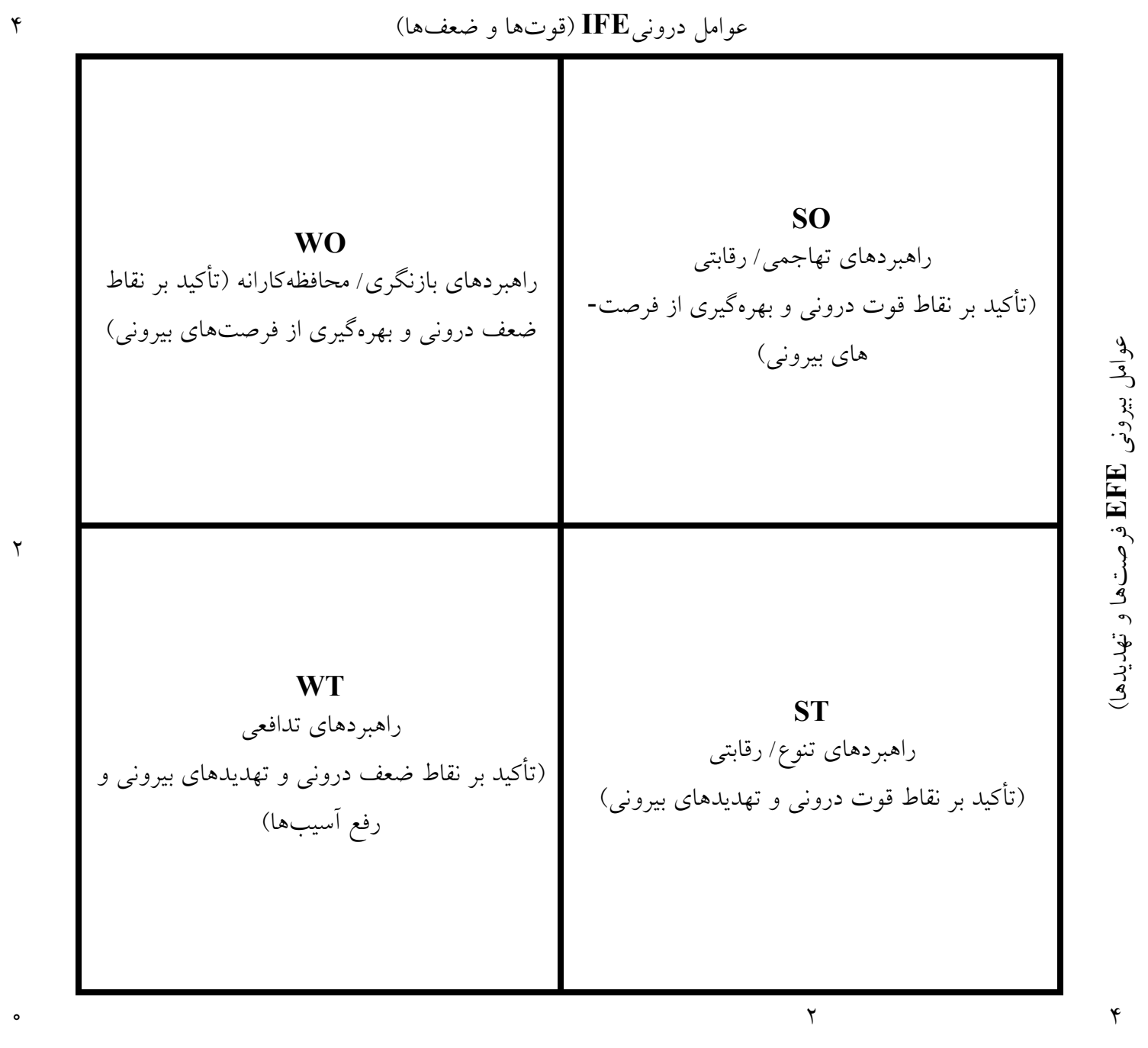

شكل r. ماتريس عوامل بيرونى و درونى مؤثر بر اجراى طرح يرداخت بابت خدمات اكوسيستم 
آنترويى يكى مفهوم باهميت در علوم اجتمـاعى، فيزيكسى و

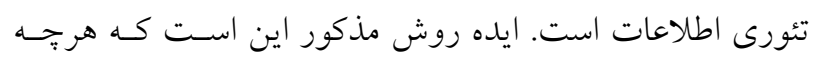

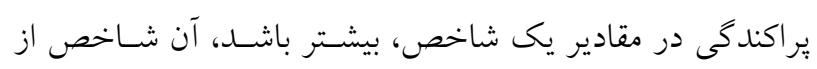
اهميت بيشترى برخوردار است. تصميم گيرى خجندمعياره معمولاً بر اساس ماتريس ارائهشده در جدول Y بهمنظور استفاده از نظـر

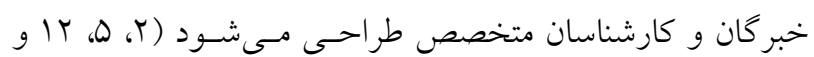

آنترويى در نظريه اطلاعات، يك معيار عدماطمينان است كه

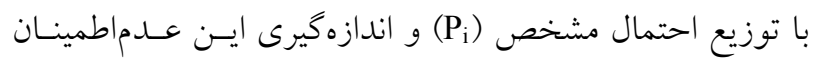
(E) توسط شانون بيان شده است (T، هو و YV).

\section{$E_{i}=\mathrm{S}\left(P_{1}, P_{2}, \ldots, P_{n}\right)=-\mathrm{k} \sum_{i=1}^{n}\left[P_{i}, \operatorname{Ln} P_{i}\right]$}

مقدار ثابت است و بهمنظور اينكه E بين صـفر و يـك باشـــ

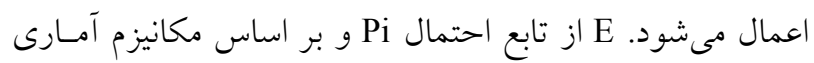

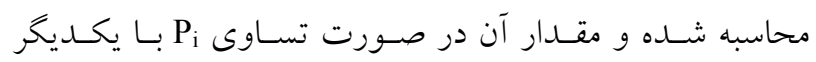

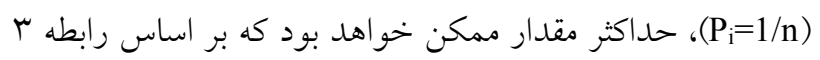
محاسبه مىشود.

$$
-\mathrm{k} \sum_{i=1}^{n} P_{i} \cdot \ln P_{i}=-\mathrm{k} \operatorname{Ln} \frac{1}{n}
$$

مقدار K از رابطه ثل محاسبه مىشود:

$$
\mathrm{K}=\frac{1}{\ln (m)}
$$

ماتريس تصميم گيرى حاوى اطلاعاتى است كه آنترويى مىتواند

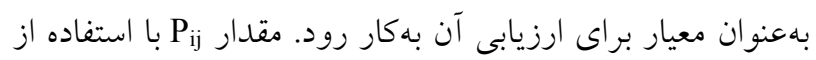
رابطه ه محاسبه مىشود.

$$
\mathrm{P}_{\mathrm{ij}}=\frac{\mathrm{a}}{\sum_{\mathrm{i}=1}^{\mathrm{m}} \mathrm{a}_{\mathrm{ij}}} ; \forall_{\mathrm{ij}}
$$

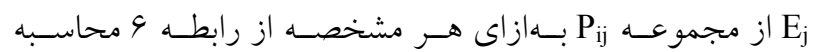
مىشود. $E_{j}=-k \sum_{i=1}^{m}\left[P_{i} \operatorname{Ln} P_{i}\right] ; \forall_{i j}$

عدماطمينان يا درجه انحـراف (d) از اطلاعـات بـهدسـتآمــده
$\mathrm{n}=\frac{\mathrm{NZ} Z^{2} \mathrm{p}(1-\mathrm{p})}{N d^{2}+Z^{2} \mathrm{p}(1-\mathrm{p})}$

$\mathrm{Z}=1.96$

d=0.05

$\mathrm{q}=1-\mathrm{p}$

$\mathrm{Z}=\mathrm{t}$

در بين كارشناسان خبره و تصميم گير در سطح شهرستان، استان

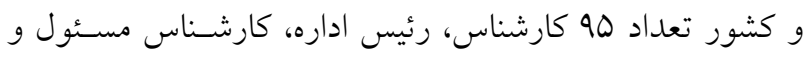

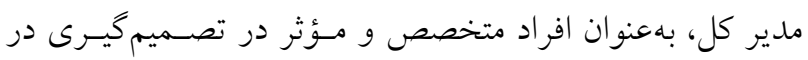

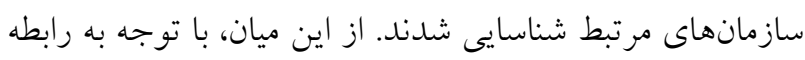

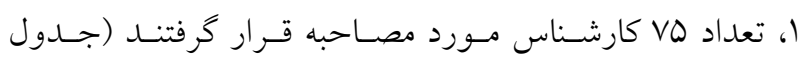

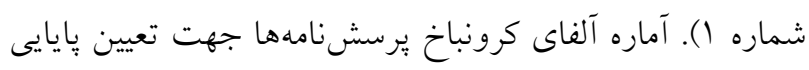

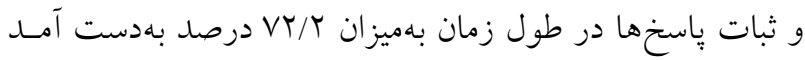

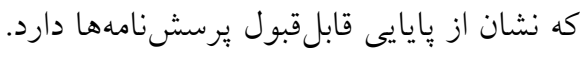

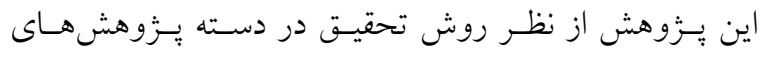

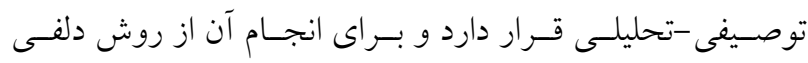

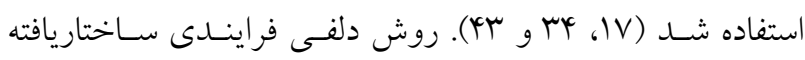

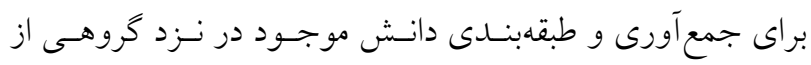
كارشناسان و خبركان است كه از طريق توزيع يرسشنامههايى در

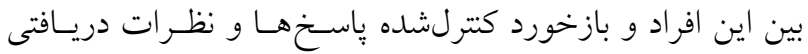

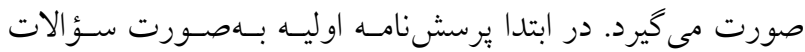
انتها-باز بـراى شناسـايى نقــاط قـوت و ضـعف و فرصـتهــا و

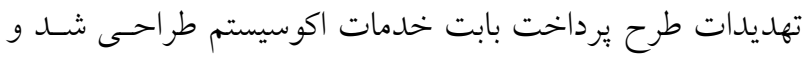

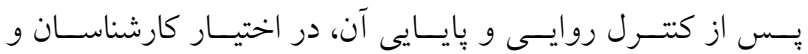

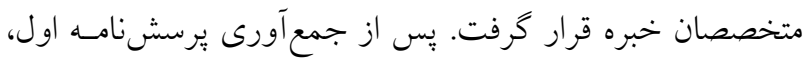

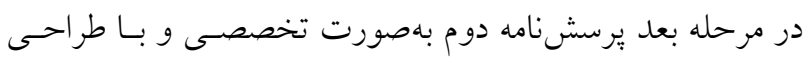

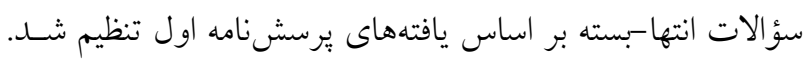

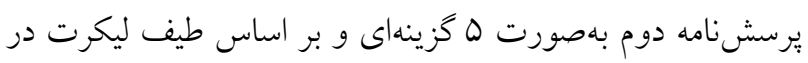

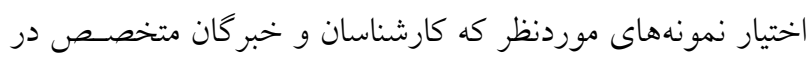

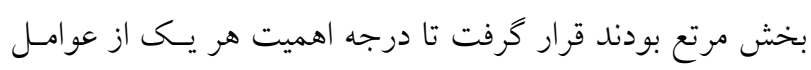

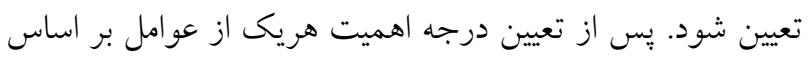

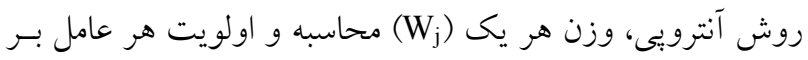

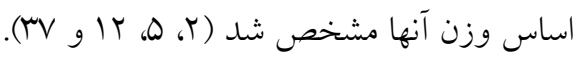


جدول ا. تعداد شركت كنندگان در تعيين عوامل مؤثر بر اجراى طرح PES

\begin{tabular}{|c|c|c|}
\hline درصد & 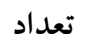 & نام سازمان يا اداره \\
\hline Mq & rV & اداره كل منابع طبيعى و آبخيزدارى استان \\
\hline ir & 9 & اداره كل حفاظت محيطزيست استان \\
\hline $10 / 9$ & $\wedge$ & شركت آب منطقهاى استان \\
\hline$\Delta / r$ & r & اداره منابع طبيعى و آبخيزدارى شهرستان \\
\hline r & $r$ & سازمان مديريت و برنامهريزى استان \\
\hline 19 & ir & دفتر امور مراتع كشور \\
\hline ir & 9 & دفتر آبخيزدارى و حفاظت خاك كشور \\
\hline$r$ & r & سازمان برنامه و بودجه كشور \\
\hline 100 & vo & جمع \\
\hline
\end{tabular}

جدول r. - اتريس تصميم گيرى جندمعياره

\begin{tabular}{|c|c|c|c|c|}
\hline \multicolumn{4}{|c|}{ معيار j } & \multirow{2}{*}{ كزينه i } \\
\hline$X_{n}$ & . & . & $\mathrm{X}_{1}$ & \\
\hline$a_{n 1}$ & . & . & $\mathrm{a}_{11}$ & $\mathrm{~A}_{1}$ \\
\hline . & . & . & . & . \\
\hline . & . & . & . & . \\
\hline . & . & . & . & . \\
\hline $\mathrm{amn}_{\mathrm{mn}}$ & . & . & $\mathrm{a}_{1 \mathrm{~m}}$ & $\mathrm{~A}_{\mathrm{m}}$ \\
\hline
\end{tabular}

تحليل وضعيت دام موجود و مجاز مراتع و ارتباط آن با طرح PES در ادامـه، وضـعيت دام موجـود و مجـاز از ديـــاه قـوانين و و

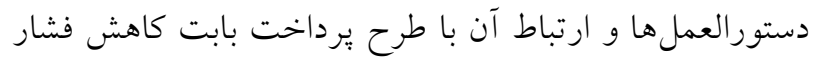
جراى دام بر مراتع و حالتهاى مختلف دام و دامدار در مراتع

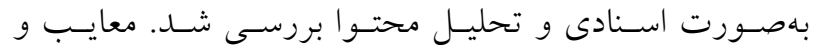

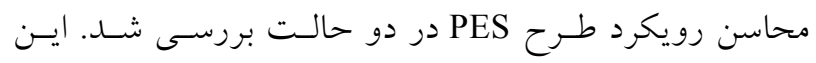

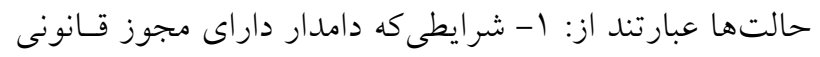

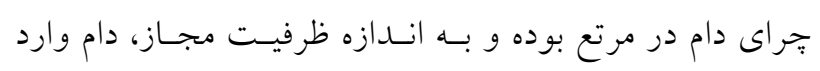

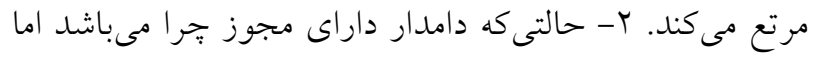
دام مازاد بر مجوز وارد مرتع مى كند. در نهايت بهتـرين كزينسه

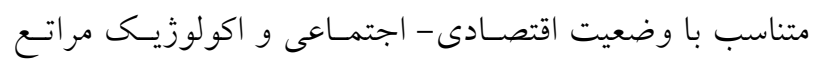
ييشنهاد شد.
براى شاخص j ، بيان مى كند كـه شـاخص مربـوط بـهـ (j) جـهـ

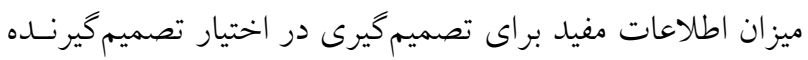
قرار مى دهد و مقدار آن بر اساس رابطه V محاسبه مى مئود. $d_{j}=1-E_{j} ; \forall_{i j}$

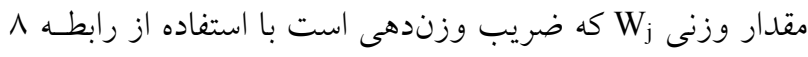

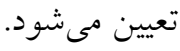

$$
W_{j}=\frac{d_{j}}{\sum_{i=1}^{m} d_{j}} ; \forall_{j}
$$

با توجه به رابطه V مىتوان درجه اهميت هر يـك از معيارهـاى

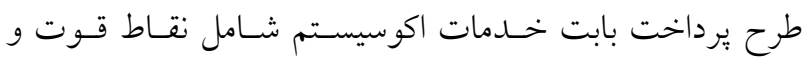
ضعف و فرصتها و تهديدها را بهدست آورد. 
در يروانه مرتعدارى قيد شده است. دام مازاد بر ظرفيـت يروانـهـ جرا يا ظرفيت مرتع، دام غيرمجاز تلقى مىشود. بر اسـاس مـاده

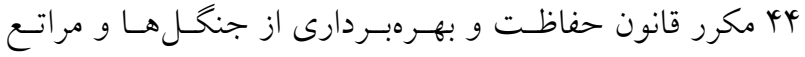
كشور و اصلاحيه شيوهنامه فنى اجرايسى بهـرهبــردارى از مراتـع كشور، به دام مازاد و دامدار غيرمجاز هيج ارزشى داده نمى شـود و با آنها برخورد قانونى صورت مى گيرد (1ل و باتها). ז- از نظر قوانين نظام داميرورى كشور، براى دام مولد جهه مجاز

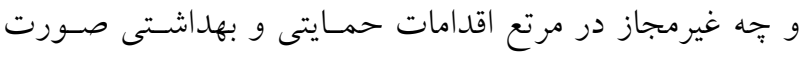
مى گيرد و بهعبارتى، قوانين اين بخش به دام مولد، نخاه مجـاز و

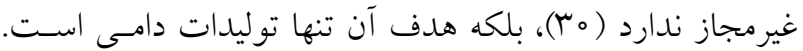

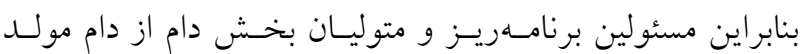

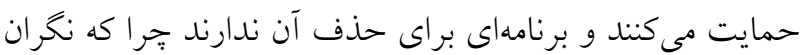
توليدات دامى هستند و حفظ مراتع در اولويتهاى بعـدى آنها

در جدول شماره ه، دو حالت مختلف در بهرهبـردارى از مراتع منطقه مورد مطالعه و بههمـين ترتيـب در مراتـع كشـور از نخــاه سيستم يرداخت بابت خدمات اكوسيستم ارائه شده و محاسن و معايب هريك بيان شده است. حالـت اول طـرح برداخـته، بـهـ

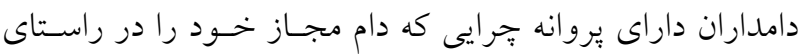
بهبود كاركردهاى تنظيمى بهطور داوطلبانه كاهش مىدهند توجه دارد. اين حالت كمترين عيب و بيشترين محاسـن را در شـرايط فعلى كشور كه مرتع تحت مالكيت دولت است داشته و حالـت تشويقى براى مرتعداران دارد.

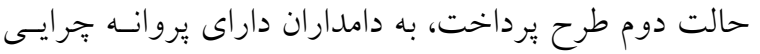

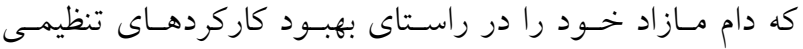
كاهش مىدهند توجه دارد. اين حالت، محاسن كمترى نسبت به حالـت اول داشـته و رويكــد حمايست از دامــاران خصوصـاً دامداران با دام كمتر دارد، اما يرداخت به دامـداران بـا دام مـازاد

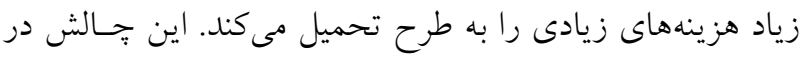

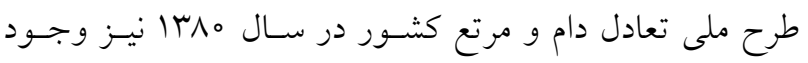

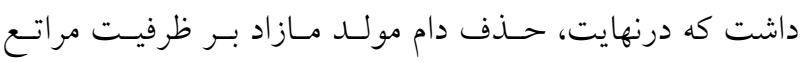
صورت نخرفت و طرح با شكست روبرو شد (14).

بررسى نقاط قوت و ضعف و تهديدات و فرصتها در مسير

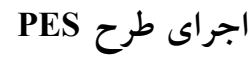

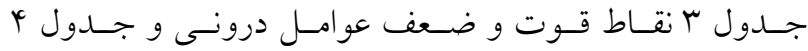
فرصتها و تهايدهاى بيرونسى را ارائسه مسدهـــ. در مجمسوع،

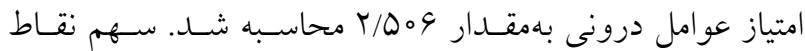

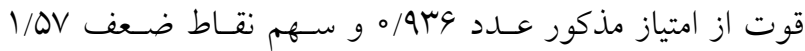
است. امتياز نقاط ضعف بر نقاط قوت برتــى دارد و از ايـنرو بايد نسبت به رفع نقاط ضعف اقدام نمود.

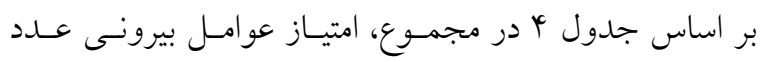

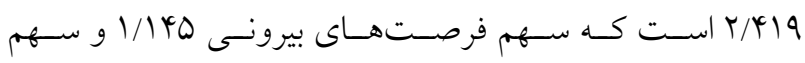

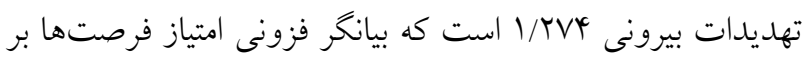

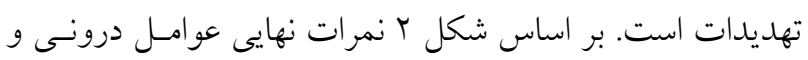

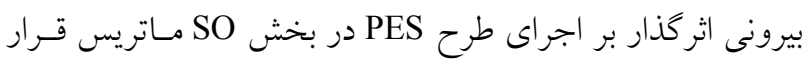

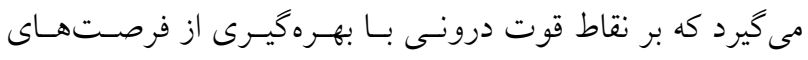
بيرونى تأكيد دارد و يك رويكرد رقابتى تهاجمى را ارائه مى كند.

\section{ديدكاههاى قانونى نسبت به دام و دامدار مجاز و غيرمجــاز و ارتباط آن با برنامه PES در وضع موجود} مرتعداران در صورتى مىتوانند از مرتع استفاده كنند كـه مجـوز

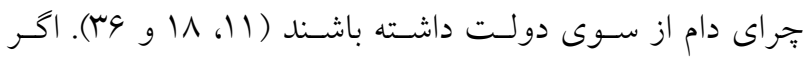
دامدارى بدون اطلاع يا عذر موجه دامدارى را ترى كند بِروانسه

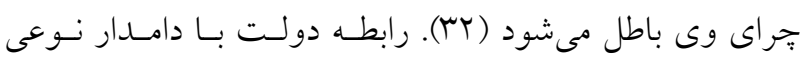

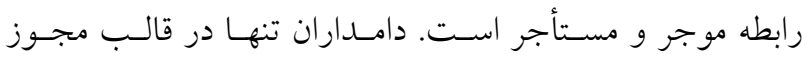

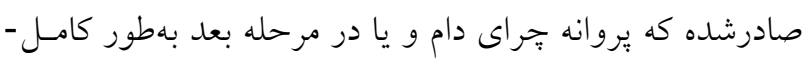

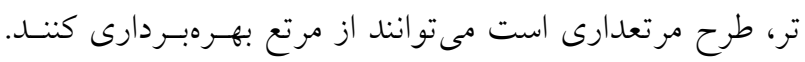
حدود اختيارات دامداران در مجوز صادرشده اعلام مسى فـود و

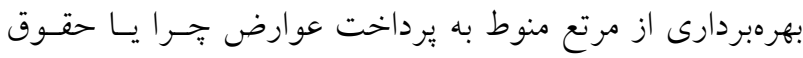

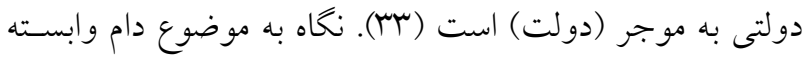
به مرتع از ديدكاه قوانين به شرح زير است. 1- از نظر قوانين حاكم بر مرتع، دام مولد به دو دسته دام مجـاز و دام غيرمجاز تقسيم مىشود. دام مجاز، تعداد دامى اسـت كـهـ 
جدول r. اولويتبندى عوامل درونى مؤثر بر طرح برداخت بابت خدمات اكوسيستم مرتع

\begin{tabular}{|c|c|c|c|c|c|}
\hline 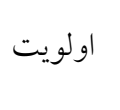 & 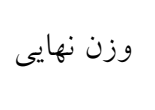 & ضريب & نمره & نقاط قوت طرح & شماره \\
\hline r & $0 / 149$ &.$/ 04$ & $r / \omega$ & كمك به كاهش شدت بهرهبردارى و افزايش كاركردهاى اكوسيستم & 1 \\
\hline$\varphi$ & O/TM & $0 / 0$ pr & $r / \omega$ & سهولت اجرا در مراتع افرازى با بهرهبردار كم & $r$ \\
\hline 9 & $0 / 11$ & $\circ / 0 \mu \mathrm{V}$ & $r$ & قابل اندازهيرى بودن اثرات طرح & r \\
\hline$\wedge$ & $0 / 091$ & $\circ / \circ$ & $r / \Delta$ & اثربخشى سريعتر نسبت به ساير روشها & r \\
\hline$\wedge$ & $\circ / 091$ & $\circ / 0 \mu \mathrm{V}$ & r & مشخص مبودن گروداران & 0 \\
\hline$\wedge$ & $0 / 091$ & $\circ / 0 r V$ & r & وجود ابزار لازم جهت اجرا مثل نيرو و تخصص & 9 \\
\hline$\wedge$ & $0 / 091$ & ०/ rV & r & يذّيرش طرح از سوى فروشندگان & V \\
\hline 9 & $0 / 0 V G$ & .01 & $r / Q$ & آشنايى برخى از مرتعداران با برنامههاى اجرايى مرتع (مرتعداران بيشرو) & $\wedge$ \\
\hline 11 & $0 / 041$ & ०/० & $r / Q$ & يذيرش طرح از سوى خريداران & 9 \\
\hline \multirow[t]{2}{*}{ ir } & $0 / 044$ & $\circ \%$ & $r / Q$ & وجود تشكل ها يا واسطهها براى هماهنگى & 10 \\
\hline & $0 / 949$ & $0 / M Q Y$ & rq & جمع نقاط قوت درونى طرح & 11 \\
\hline 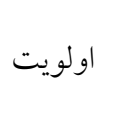 & وزن نهايى & ضريب اهميت & نمره & نقاط ضعف درونى طرح & شماره \\
\hline 1 & $0 / 190$ & $\circ / 0 \Delta \Delta$ & $4 / 0$ & ضعف در نظارت و كنترل ظرفيت مجاز مرتع & 1 \\
\hline r & $0 / 149$ & $0 / 049$ & r & عدم وجود قوانين حمايتى و يشتيبان مربوط به PES & $r$ \\
\hline r & $0 / 144$ & $0 / 049$ & r & وجود دام مازاد بر ظرفيت & r \\
\hline r & $0 / 149$ & $0 / 049$ & c & عدم تثيت حقوق مالكيت بهويزه در مراتع روستايى و مشاعى & r \\
\hline$\psi$ & O/TKA & $0 / 049$ & $r / 0$ & وابستكى شديد مرتع داران به مرتع & 0 \\
\hline 0 & O/TY & $0 \% 49$ & r & عدم تجربه قبلى در اجراى طرح PES & 9 \\
\hline 9 & $\circ / 11$ & $\circ / \mu_{V}$ & r & تأمين منابع اعتبارى طرح PES & V \\
\hline V & $\circ / \circ 9 \Lambda$ & $0 / 049$ & r & عدم وجود يك الكوى مورد تأييد درمورد نحوه برداخت & $\wedge$ \\
\hline$\wedge$ & $\circ / 091$ & $\circ / r^{\prime}$ & r & عدم توسعه مشاغل خارج از مرتع ع & 9 \\
\hline 10 & $\circ / \circ V$ & 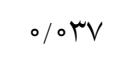 & $r$ & تغيير مكرر قيمت نهادههاى دامى و گوشت & 10 \\
\hline 10 & $\circ / \circ V^{\mu}$ & $\circ / 0 r v$ & r & عدم|طمينان فروشندكان خدمت از يرداختها & 11 \\
\hline 10 & $\circ / \circ v^{n}$ & $\circ / r^{\prime}$ & r & عدماطمينان خريداران خدمت از كاهش دام & Ir \\
\hline 10 & $\circ / \circ V$ & $\circ / 0 r V$ & r & بى اعتمادى به واسطهها در طرح يرداخت & Ir \\
\hline Ir & $0 \% 49$ & o/OrY & r & ناهماهنكى و مو ازىكارى دستخاههاى متولى اجرا & 14 \\
\hline ir & $0 / 049$ & $\circ / \circ$ & $\Gamma / \Delta$ & عدم مشاركت برخى از مرتعداران & 10 \\
\hline \multirow[t]{3}{*}{14} & $\circ / \circ$ & $\circ \%$ & $T / \Delta$ & عدم تغيير نخرشها، عادات و رفتارها در كوتاهمدت & 19 \\
\hline & $1 / Q V$ & $0 / 949$ & Qr & جمع نقاط ضعف درونى & IV \\
\hline & $T / 0 \circ \varphi$ & 1 & $\Delta r$ & جمع عوامل درونى (قوت+ضعف) & 11 \\
\hline
\end{tabular}


جدول f. اولويتبندى عوامل بيرونى مؤثر بر طرح برداخت بابت خدمات اكوسيستم مرتع

\begin{tabular}{|c|c|c|c|c|c|}
\hline 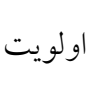 & 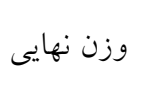 & ضريب اهميت & نمره & 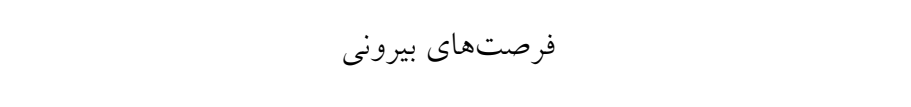 & شماره \\
\hline$r$ & $0 / 14 D$ & $\circ / \circ \Delta \wedge$ & $\varphi / 0$ & افزايش كاركردهاى غيربازارى مراتع & 1 \\
\hline r & ०/ra & .040 & $r / \phi$ & ارتقاء و تنوعبخشى به فون و فلور منطقه & r \\
\hline 0 & $0 / 119$ & ००५q & r & تغيير در سيستم برنامهريزى و بودجه در سطح استانى و ملى & $r$ \\
\hline 0 & $0 / 119$ & o/०rq & r & ايجاد بازار فرضى براى كالاهاى غيربازارى مرتع & $r$ \\
\hline V & $\circ / 1 \circ r$ & $\circ / 0 Q T$ & r & افزايش ظرفيت جرايى مراتع در آينده & Q \\
\hline$\wedge$ & $.09 V$ & ००५q & r & لحاظكردن ارزش كاركردهاى غيربازارى مراتع در حسابهاى منطقهاى و ملى & 9 \\
\hline 9 & $0 / 09$ & .040 & $r / \phi$ & بهرهمندى فروشندگان و خريداران خدمات مرتع & V \\
\hline 10 & $\circ / \circ V V$ & $\circ / \circ \varphi_{9}$ & r & سرمايه گذارى بيشتر در منطقه با همافزايى ناشى از اجراى طرح & $\wedge$ \\
\hline 11 & $0 / 090$ & O०Mt & $r / Q$ & افزايش بينش و آكاهى مرتعداران & 9 \\
\hline 11 & .090 & O०Mt & $r / Q$ & فقرزدايى با بهبود اشتغال در مراتع & 10 \\
\hline 11 & $0 / 090$ & סOrt & $r / Q$ & ايجاد فرصت براى استفاده از ساير يتانسيلهاى مرتع & 11 \\
\hline Mr & $\circ / \circ \Delta r$ & \%०YG & r & ايجاد مشاركت گروداران در احياى مراتع & ir \\
\hline \multirow[t]{2}{*}{19} & $0 / 019$ &.$/ 014$ & 1 & استفاده از كمكهاى فنى و اعتبارى سازمانهاى بينالمللى & Ir \\
\hline & $1 / 140$ & $\circ / 49 \circ$ & $\mu_{\Lambda}$ & جمع فرصت هاى بيرونى & 14 \\
\hline 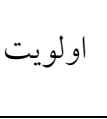 & وزن نهايى & ضريب اهميت & نمره & تهايدهاى بيرونى & شماره \\
\hline 1 & $\circ / I V+$ & $\circ / \circ \Delta \wedge$ & $4 / 0$ & ترجيح كاركردهاى بازارى بر غيربازارى توسط برنامهريزان و سياست گذاران & 1 \\
\hline r & $\circ / / Q \Lambda$ &.$/ 040$ & $r / \Delta$ & 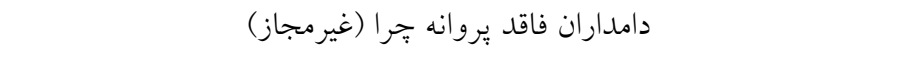 & r \\
\hline$r$ & $\circ / 1 r \Delta$ & $\circ \% 40$ & $r / Q$ & سياستهاى متغير، متفاوت و دو كانه سازمانهاى تصميم گير & r \\
\hline$r$ & $\circ / 1 r \Delta$ & $\circ / \circ r_{q}$ & r & خطر افزايش دام و دامدار & r \\
\hline 9 & $\circ / 114$ & $\circ \% 40$ & $r / 0$ & وجود روشهاى متفاوت ارزش كذارى و خروجى هاى متفاوت & 0 \\
\hline$\wedge$ & $\circ / \circ 9 V$ & $\circ / 0 \varphi_{q}$ & r & كاهش مشاركت دامداران در اجراى برنامههاى حفاظت و اصلاح و احياء & 4 \\
\hline$\wedge$ & $\circ / 09 V$ & $\circ / \circ \varphi_{q}$ & $r$ & تأثير مكان و زمان بر ارزش كاركردها & V \\
\hline 9 & $\circ / \circ 9$ & $\circ \% 40$ & $r / \Delta$ & عدم قطعيت در ارزش كذارى خدمات غيربازارى & $\wedge$ \\
\hline 10 & $\circ \circ V V$ & $0 / 0 Y 9$ & r & عدم اطمينان قطعى از نتايج طرح در بين مسئولان تصميمگير & 9 \\
\hline 10 & $\circ / \circ V$ & $\circ \%$ rq & r & وجود عو امل غيرقابل بيشبينى در طرح مانند خشكسالى و ترسالى & 10 \\
\hline 10 & $\circ \% 4 \wedge$ & \%०rt & $r / \Delta$ & خطر افزايش شدت جرا در مراتع همجوار & 11 \\
\hline 14 & o/०rq & $0 / 0 Y 9$ & r & خطر افزايش تخريب مرتع در صورت مقطعىبودن و عدم استمرار طرح & ir \\
\hline \multirow[t]{3}{*}{10} & OOHT & O/Ort & $r / Q$ & ايجاد اختلافات بين دامداران داراى دام مجاز زياد با دامداران خردهيا & ir \\
\hline & $1 / T V Y$ & $\circ / 01 \circ$ & $r q / \Delta$ & جمع تهديدات بيرونى & 14 \\
\hline & $r / 419$ & 1 & $V V / D$ & جمع عوامل بيرونى (فرصتها+تهاديدها) & 10 \\
\hline
\end{tabular}


جدول ه. حالتهاى مختلف در ارتباط با طرح يرداخت بابت خدمات اكوسيستم مرتع

\begin{tabular}{|c|c|c|c|c|c|}
\hline معايب & محاسن & هاهش برن دامه & نوع دام & دامدار & حالت \\
\hline از ظرفيت جرايى كامل مرتع & 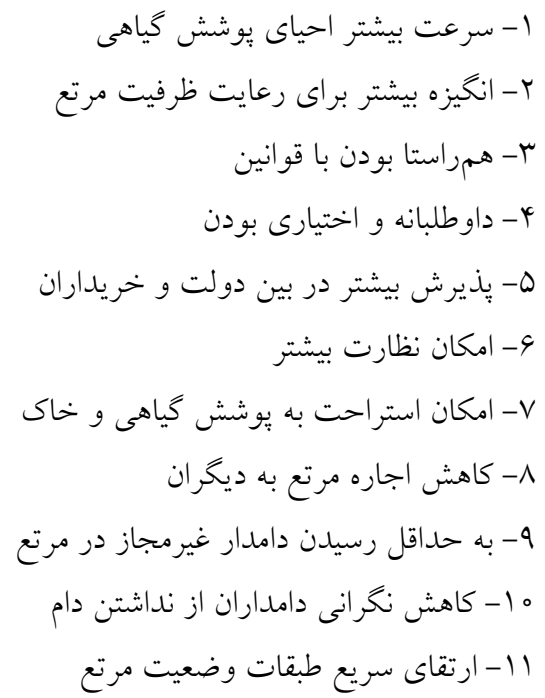 & كمتر از ظرفيت مجاز، دام & مجاز & مجاز & 1 \\
\hline
\end{tabular}

1- تشويق دامداران متخلف

r- در تضاد با قوانين موجود

ب- ماملاً اجبارى

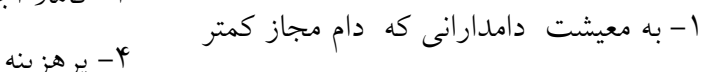
دارند توجه مى شود.

ه- سرعت كم تغيير وضعيت

مرتع

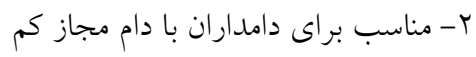
تا سقف ظرفيت مجاز، دام وارد مرتع شود.

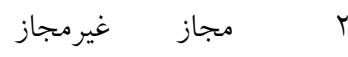

9- بذيرش كمتر در بين

خريداران

ديخر اين نقطه قوت بيان مىكند كه بايد به سمت تنسيق مراتـع مشاعى حركت نمــود و سـاماندهـى بهـرهبـرداران مـازاد را در دستور كار قرار داد. مهمترين نقطه ضـعف درونـى تأثيركـار، ضعف در نظارت و كتترل ظرفيت مجاز مرتع است. اين نقطـه-

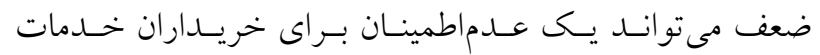
اكوسيستم ايجاد كند كه با ايجاد و تقويت يك سيستم كنتـرل و نظارت مىتوان اين نخرانى را برطرف كرد. اين سيستم بايسـ بـهـ كونهاى باشد كه هم خريداران كه گروداران و استفادهكنند كان از

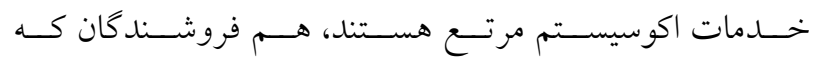
توليدكنندكان خــدمات اكوسيستم هسـتند (مرتـعداران) و هـم

\section{بحث و نتيجه كيرى}

مهمترين نقطه قـوت درونسى طـرح ثرداخـت بابست خـدمات

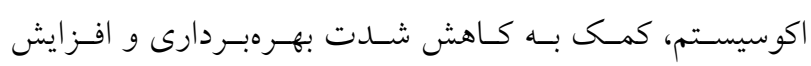
كاركردهاى اكوسيستم مرتع اسـت. ايسن بــينمعنسى اسـت كـهـ

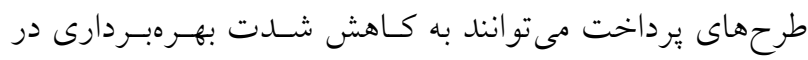
مرتع كمى كنند. دومين نقطه قوت عوامل درونى، سهولت اجرا در مراتع افرازى با تعداد بهرهبردار كم است كه اين نقطـهــوت نشان مىدهد در مراتع با بهرهبردار كمتر، اين برنامسه راحست بــر

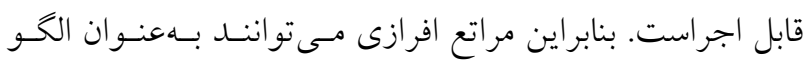
(يايلوت)، نامزد شروع اجراى طـرح برداخـت باشــند. از سـوى 
مىدهد كه تأكيد تنها بر طـرح برداخـت بـدون در نظـر خـرفتن

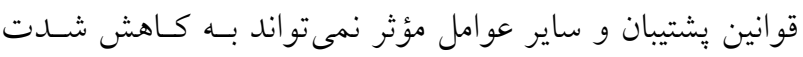

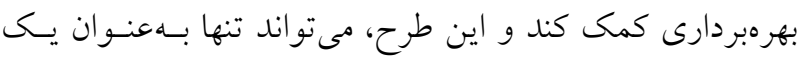

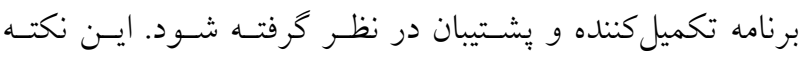

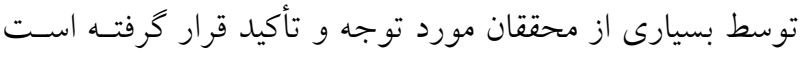

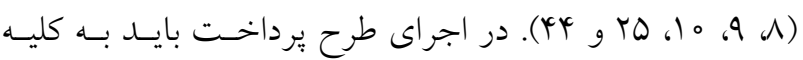
ارزشها و خدمات اكوسيستم توجه داشت تا هزينههاى مبادلـهـ-

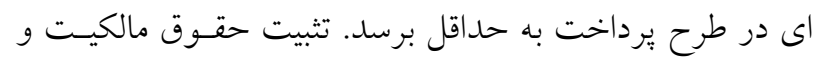

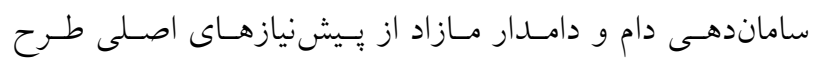

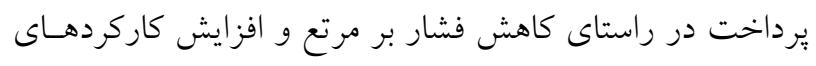

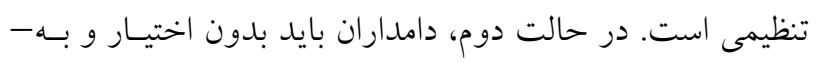

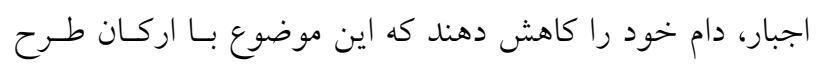

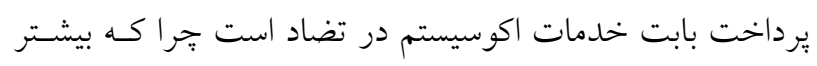

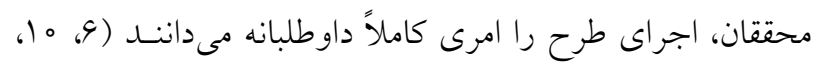

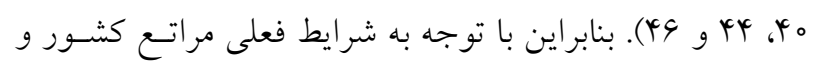

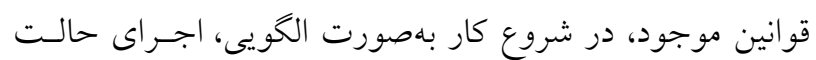

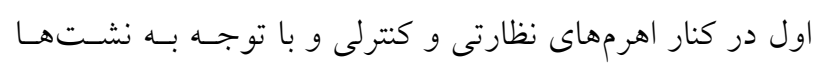

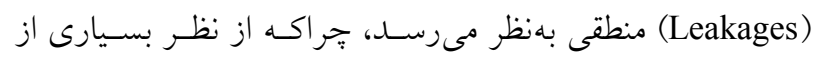
محققان، طرحهاى PES در كنار ساير اقدامات مى توانند مـؤثر و

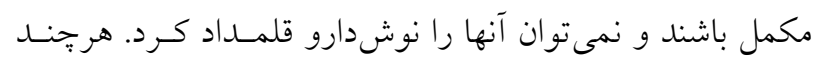

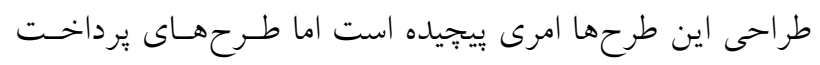

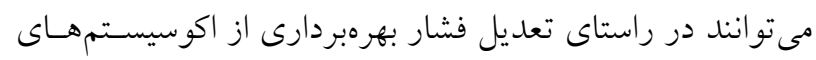

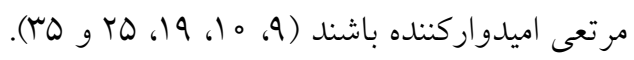

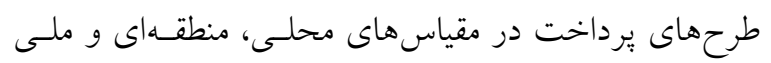

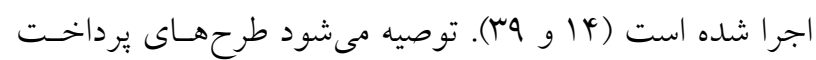
بابت خدمات اكوسيستم در مقياس محلى تنظيم شـود تـا كليـه

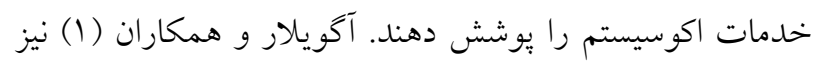

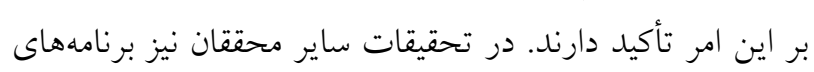

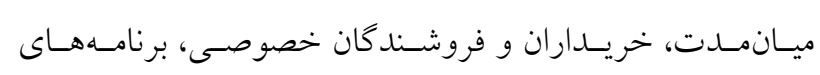

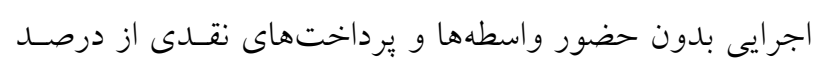

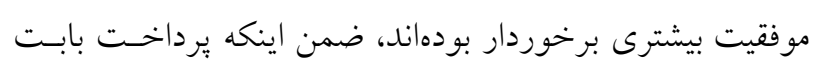

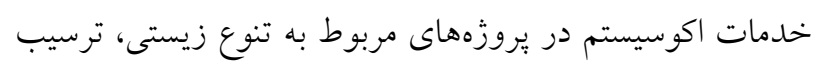

هماهنخ كنند كان كه بهطور عمده دستخاههاى دولتى، تشكلهـا،

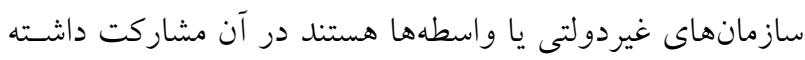
باشند. اين نكته توسـط بسـيارى از محققــان مـورد تأكيــ قـرار

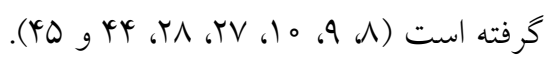
عدم تثبيت حقوق مالكيت، بلويزه در مراتع روستايى نيـز از

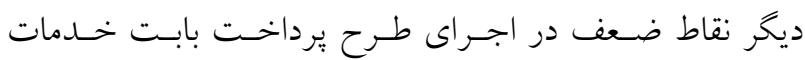

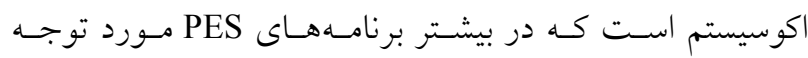

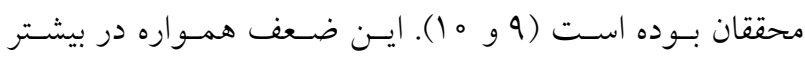

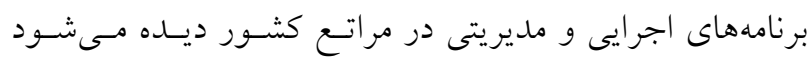

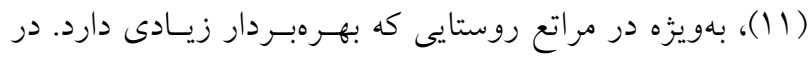

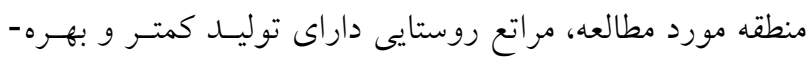

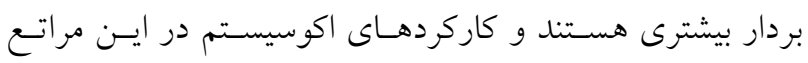
كمتر است. نتايج تحليل SWOT در بخـش عوامـل خـارجى تأثيركـذار

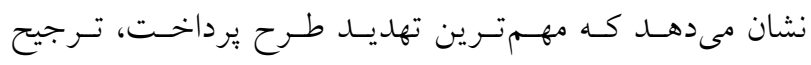

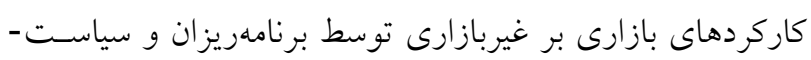

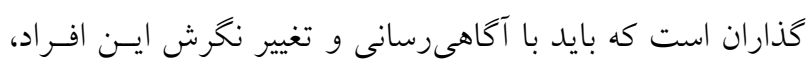

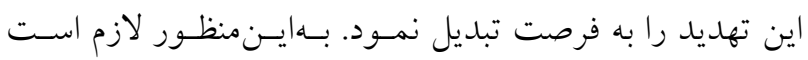

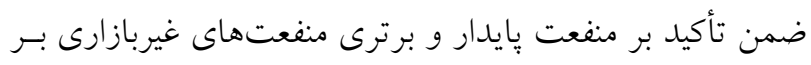

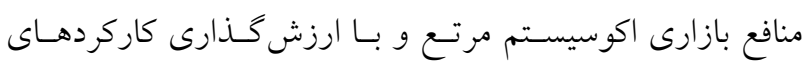

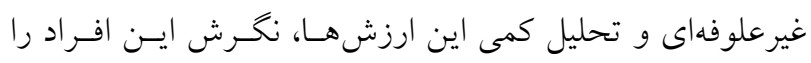

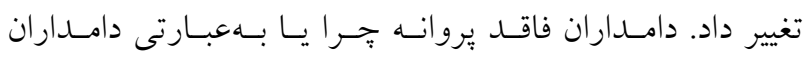

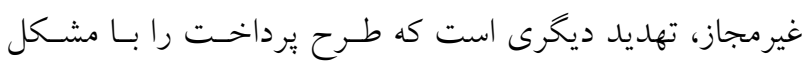

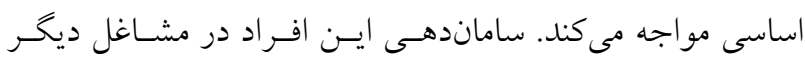

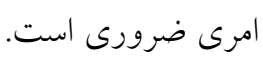
فرصتهاى بيرونى اولويتدار از نظر خبر كان و كارشناسـان

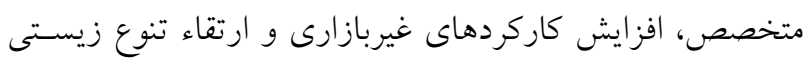

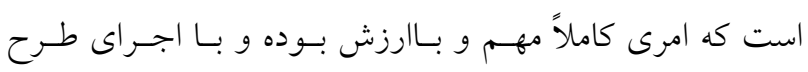

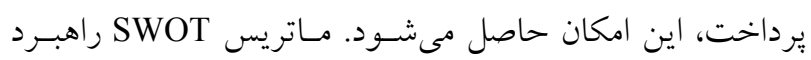

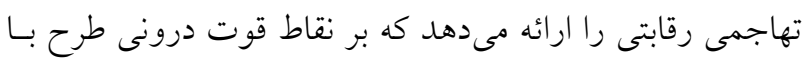

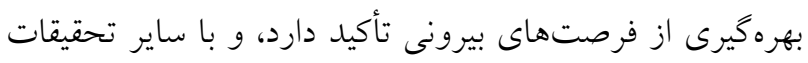

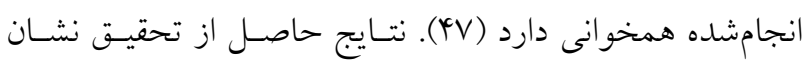




$$
\begin{aligned}
& \text { مجاز بيشترى كاهش يابد هزينههاى طرح برداخت بيشتر شده و } \\
& \text { كربن و تثبيت اراضى شيبدار موفقيت بيشترى داشتهانـد (l| ا و } \\
& \text { افزودگى (Additionality) نيز با گذشت زمان بيشتر خواهد بود } \\
& \text { و به همين ترتيب، سرعت ارتقاء طبقـه وضـعيت مرتـع بـه يـك }
\end{aligned}
$$

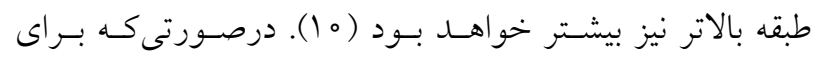

$$
\begin{aligned}
& \text { كاهش دام در ازاى دريافت مبلغى معادل سود ناشى از دامدارى } \\
& \text { متكى به مرتع، جايخاهى در قوانين تعيين شود و مرتعداران بـهـ- } \\
& \text { صورت داوطلبانه نسبت به كاهش دام مجاز خود اقـدام نماينـد } \\
& \text { جراى دام در مراتع كاهش يافتـه و شـاهد تغييـر در وضـعيت و }
\end{aligned}
$$

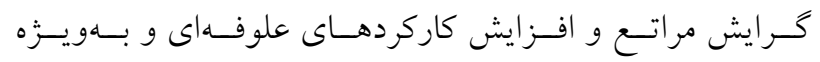

$$
\begin{aligned}
& \text { غيرعلوفهاى مراتع (ازجمله كاركردهاى تنظيمى) خواهيم بود. } \\
& \text { حالت دوم ضمن اينكه در عمل داراى معايب بىشمارى نسبت } \\
& \text { به حالت اول است در بين خريداران و نهادهاى دولتى مجـرى } \\
& \text { قانون مورد استقبال نيست و با توجه به قوانين حاكم بر مراتع و } \\
& \text { دستاوردهاى اين تحقيق توصيه نمىشود. درجايىكـه دام مـازاد } \\
& \text { وجــود دارد در خـام اول، آمـوزش و آخـاهى دادن بـهـ دامــداران } \\
& \text { متخلف و در كام بعد، استفاده از اهرمهاى قيدشده در ضوابط و } \\
& \text { شرايط بهرهبردارى از مراتع كشـور از جملـه صـدور اخطاريـه } \\
& \text { ابطال مجوز جرا و در نهايت در صورت عدم توجه، اسـتفاده از }
\end{aligned}
$$

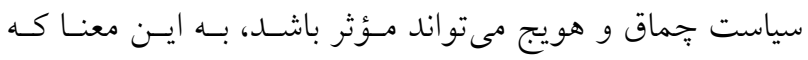

$$
\begin{aligned}
& \text { ضمن برخورد قانونى و تنبيهى با دامدارانى كـه داراى دام مـاز اد } \\
& \text { هستند، در مراتعى كه دامداران متناسب با ظرفيت مرتع دام وارد } \\
& \text { مى كنند سياستهاى تشويقى در دستور كار قرار گيرد. همجنسين } \\
& \text { توصيه مىشود طرح PES بهطور داوطلبانه اجرا شده و برداخت } \\
& \text { بابت كاهش دام مجاز در دسـتور كـار باشـــ. هرجهـه تعـداد دام }
\end{aligned}
$$

\section{منابع مورد استفاده}

1. Aguilar, F. X., E. A. Obeng and Z. Cai. 2018. Water quality improvements elicit consistent willingness-to-pay for the enhancement of forested watershed ecosystem services. Ecosystem Services 30: 158-171.

2. Asgharpour, M. J. 2018. Multiple criteria decision making. University of Tehran Press, Tehran. (In Farsi)

3. Asner, G. P., A. J. Elmore, L. P. Olander, R. E. Martin and A. T. Harris. 2004. Grazing systems, ecosystem responses, and global change. Annual Review of Environment and Resources 29: 261-299.

4. Braat, L. and R. De Groot. 2012. The ecosystem services agenda: bridging words of natural sciences and economics conservation and development and private policy. Ecosystem Services 1(1): 4-15.

5. Dawes, R. M. 1964. Social selection based on multidimensional criteria. The Journal of Abnormal and Social Psychology 68(1): 104-109.

6. De Groot, R., S. Alkemade, R. Braat, L. Hein and L. Willemen. 2010. Challenges in integrating the concept of ecosystem services and values in landscape planning, management and decision making. Ecological Complexity 7 : 260-272.

7. Cochran, W. G. 1963. Sampling techniques, $2^{\text {nd }}$ Edition. John Wiley and Sons, New York.

8. Engel, S., S. Pagiola and S. Wunder. 2008. Designing payment for environmental services in theory and practice: an overview of the issues. Ecological Economics 65: 663-674.

9. Engel, S. and C. Palmer. 2008. Payments for environmental services as an alternative to logging under weak property rights: the case of Indonesia. Ecological Economics 65(4): 799-809.

10. Engel, S. 2016. The devil in the detail: a practical guide on designing payments for environmental services. International Review of Environmental and Resource Economics 9(1-2): 131-177.

11. Eskandari, N., A. Alizadeh and F. Mahdavi. 2008. Range management policy of Iran. Pouneh Publications, Tehran. (In Farsi)

12. Ghodsipour, H. 2018. Multicriteria decision making. University of Amir Kabir Press, Tehran. (In Farsi)

13. Ghorbani, M. and A. Firouzzare. 2010. Introduction of environmental valuation, $2^{\text {nd }}$ Edition. Ferdowsi University of Mashhad Press, Mashhad. (In Farsi) 
14. Grima, N., S. J. Singh, B. Smetschka and L. Ringhofer. 2016. Payment for Ecosystem Services (PES) in Latin America: analyzing the performance of 40 case studies. Ecosystem Services 17: 24-32.

15. Hanley, N., J. Shogren and B. White. 2019. Introduction to environmental economics. Oxford University Press, Oxford.

16. He, J. and T. Sikor. 2015. Notions of justice in payments for ecosystem services: insights from China's Sloping Land Conversion Program in Yunnan Province. Land Use Policy 43: 207-216.

17. Helmer, O. 1977. Problems in futures research: Delphi and causal cross-impact analysis. Futures 9(1): 17-31.

18. Inspection and Law Office. 2010. Laws collection of Iran natural recourses. Forests, Rangelands and Watershed Organization (FRWO), Ministry of Agriculture, Tehran. (In Farsi)

19. Jack, B. K., C. Kousky and K. R. Sims. 2008. Designing payments for ecosystem services: lessons from previous experience with incentive-based mechanisms. Proceedings of the National Academy of Sciences 105(28): 94659470.

20. Kajanus, M., J. Kangas and M. Kurttila. 2004. The use of value focused thinking and the A'WOT hybrid method in tourism management. Tourism management 25(4): 499-506.

21. Kinzig, A. P., C. Perrings, F. S. Chapin, S. Polasky, V. K. Smith, D. Tilman and B. Turner. 2011. Paying for ecosystem services promise and peril. Science 334(6056): 603-604.

22. Kolahi, M. 2021. Natural resources stakeholders. Journal of Water and Sustainable Development 8(1): 19-30. (In Farsi)

23. Kotler, P. 1988. Marketing management: analysis, planning, implementation and control, $6^{\text {th }}$ Edition. Prentice Hall International Edition, Englewood Cliffs.

24. Millennium Ecosystem Assessment. 2005. Strengthening capacity to manage ecosystem sustainability for human well-being; a report of the Millennium Ecosystem Assessment. Available online at: www.millenniumassessment.org.

25. Muradian, R., M. Arsel, L. Pellegrini, F. Adaman, B. Aguilar, B. Agarwal, E. Corbera, D. Ezzine De Blas, J. Farley, G. Froger and E. Garcia. 2013. Payments for ecosystem services and the fatal attraction of win-win solutions. Conservation letters 6(4): 274-279.

26. Natural Resources Council. 2001. National plan of livestock and rangeland balance of Iran. Forests, Rangelands and Watershed Organization (FRWO), Ministry of Agriculture, Tehran. (In Farsi)

27. Pagiola, S. 2008. Payments for environmental services in Costa Rica. Ecological Economics 65(4): $712-724$.

28. Pagiola, S., E. Ramírez, J. Gobbi, C. De Haan, M. Ibrahim, E. Murgueitio and J. P. Ruíz. 2007. Paying for the environmental services of silvopastoral practices in Nicaragua. Ecological Economics 64: 374-385.

29. Pagiola, S. 2005. Assessing the efficiency of payments for environmental services programs: a framework for analysis. World Bank, Washington.

30. Parliament Research Center. 2009. Integarated law of livestock husbandry of Iran. Islamic Parliament of Iran, Tehran. (In Farsi)

31. Rangeland Affairs Office. 2002. Information and audit of rangelands. Natural Resources and Watershed Management General Office of Chaharmahal \& Bakhtiari, Shahrekord. (In Farsi)

32. Rangeland Affairs Office. 2020. Instruction rethinking of rangelands utilization (technical implementation), Forests, Rangelands and Watershed Organization (FRWO), Ministry of Agriculture, Tehran. (In Farsi)

33. Rangeland Affairs Office. 2017. Contract of range management design, No: 96.1.19972. Forests, Rangelands and Watershed Organization (FRWO), Ministry of Agriculture, Tehran. (In Farsi)

34. Rowe, G. and G. Wright. 1999. The Delphi technique as a forecasting tool: issues and analysis. International journal of forecasting 15(4): 353-375.

5 Salzman, J. 2005. Creating markets for ecosystem services: notes from the field. New York University Law Review 80 : 870.

36. Shamekhi, T. 2010. Laws and natural resources management (rangelands and forests). Tehran University Press, Tehran. (In Farsi)

37. Simon, H. A. 1955. A behavioral model of rational choice. The quarterly journal of economics 69(1): 99-118.

38. Suttie, J. M., S. G. Reynolds and C. Batello. 2005. Grasslands of the world, Vol. 34. Food \& Agriculture Organization (FAO). Available online at: http://www.fao.org/3/y8344e/y8344e05.htm.

39. Smith, S., P. Rowcroft, M. Everard, L. Couldrick, M. Reed and H. Rogers. 2013. Payments for ecosystem services: a best practice guide. Department for Environment, Food and Rural Affairs, London.

40. Tacconi, L. 2012. Redefining payments for environmental services. Ecological Economics 73: 2936.

41. Watershed Management Assistance. 2004. Survey of watershed management of Karsanak basin. Natural Resources and Watershed Management General Office of Chaharmahal \& Bakhtiari, Shahrekord. (In Farsi)

42. Wheelen, T. L. and J. D. Hunger. 2012. Strategic management and business policy, $5^{\text {th }}$ Edition. Pearson Education, New Jersey. 
43. Woudenberg, F. 1991. An evaluation of Delphi. Technological forecasting and social change 40(2):131-150.

44. Wunder, S. 2005. Payment for environmental services: some nuts and bolts. Occasional Paper, No. 42. Center for International Forestry Research, Jakarta, Indonesia.

45. Wunder, S., S. Engel and S. Pagiola. 2008. Taking stock: a comparative analysis of payments for environmental services programs in developed and developing countries. Ecological Economics 65(4): 834-852.

46. Wunder, S. 2015. Revisiting the concept of payments for environmental services. Ecological Economics 117: 234243.

47. Zakeri, A., S. A. Mousavi and H. Karimzadeh. 2020. Strategies for implementing the payment approach for ecosystem services in rangeland management in North Khorasan province. Rangland 14(2): 325-337. (In Farsi) 


\title{
Strategic Analysis of Payments Approach for Ecosystem Services in Order to Balance the Utilization Level in Rangeland Ecosystems
}

\author{
A. M. Mohammadi ${ }^{1}$, S. A. Mousavi ${ }^{1 *}$, S. Soltani Koupaei ${ }^{1}$ and Gh. H. Kiani²
}

(Received: May 01-2021; Accepted: September 04-2021)

\begin{abstract}
One of the ways to reduce the improper utilization on natural ecosystems is the economic valuation of ecosystem services and payment to the service providers in exchange, to reduce the causes of degradation. This approach is known as"Payment for Ecosystem Services (PES). In this research, the strategic factor analysis approach was employed to identify strengths, weaknesses, opportunities and threats (SWOT) in rangelands of Chaharmahal and Bakhtiari province. Using a questionnaire and Delphi method, through a survey of 75 experts, the factors were identified. Weighted factors and priority of each factor were determined through multi-criteria entropy decision making method. Results showed that the most important strength is "reduction of grazing intensity by the implementation of PES" with a score of 0.149 , the most important weakness is "the lack of monitoring and inspection of grazing capacity with a score of 0.165 , the most important opportunity is "improving non-market services of rangeland ecosystem" with a score of 0.145 and the most important threat is "giving preference to the market functions over non-market functions by policymakers" with the score of 0.174 . The payment scheme can be a complementary option to reduce grazing intensity if rangers voluntarily reduce their livestock.
\end{abstract}

Keywords: Economic Valuing, Strategic Factor Analysis, Market Functions, Grazing Intensity, Rangelands of Chaharmahal and Bakhtiari Province

1. Rangeland and Watershed Management Department, Natural Resources Faculty, Isfahan University of Technology, Iran.

2. Economy Department, Economy and Administrative Affairs Faculty, Isfahan University, Iran

*: Corresponding Author, Email: sarmousavi@cc.iut.ac.ir 